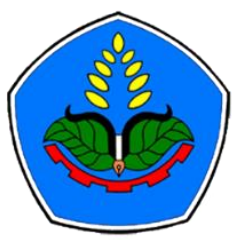

AGROPROSS

National Conference

Proceedings of Agriculture
Proceedings:

Peran Teaching Factory Di Perguruan Tinggi Vokasi Dalam

Mendukung Ketahanan Pangan Pada Era New Normal

Tempat : Politeknik Negeri Jember

Tanggal : 8-9 Juli 2020

Publisher:

Agropross, National Conference Proceedings of Agriculture

ISBN : 978-623-94036-6-9

DOI : 10.25047/agropross.2020.43

\title{
Kajian Ekonomi Melalui Pendekatan Kontribusi Komoditas Kopi Terhadap Perekonomian Provinsi Jawa Timur
}

\author{
Author(s): Rachmat Udhi Prabowo ${ }^{(1) *}$ \\ (1) Program Studi Agribisnis, Fakultas Pertanian Universitas Jember \\ * Corresponding author: rachmatudhi@unej.ac.id
}

\begin{abstract}
This study aims to determine; The contribution of coffee commodity on the economy of East Java Province, This research that was located in East Java Province used purposive method for area determination. The method used in the research was more directed to the descriptive and analytical methods. The analysis used was Input Output Analysis. The results showed that In the economy of East Java province, coffee commodity has Contribution and contribution through value of output contribution equals to Rp. 4.247 trillion or contributes $0.133 \%$ of the total output creation in East Java province and it has a contribution of gross added value of Rp. 3.821 trillion or contribute $0,226 \%$ of the total gross added created value in East Java Province. The contribution of output and gross added value of coffe commodity sub sector as a whole has a low value.
\end{abstract}

\section{Keyword:}

Contribution of Coffe;

Contribution of gross added value;

Contribution of output.;

\begin{abstract}
Kata Kunci:
ABSTRAK

Penelitian ini bertujuan untuk mengetahui; Kontribusi komoditas kopi terhadap perekonomian

Kontribusi kopi; Provinsi Jawa Timur. Penelitian yang berlokasi di Provinsi Jawa Timur ini menggunakan metode

Kontribusi output;

Kontribusi nilai tambah bruto; purposive untuk penentuan wilayah. Metode yang digunakan dalam penelitian ini lebih mengarah pada metode deskriptif dan analitik. Analisis yang digunakan adalah Analisis Output Input. Hasil penelitian menunjukkan bahwa Dalam perekonomian Provinsi Jawa Timur, komoditas kopi memiliki Kontribusi dan kontribusi melalui nilai kontribusi output sebesar Rp. 4,247 triliun atau menyumbang $0,133 \%$ dari total penciptaan output di provinsi Jawa Timur dan memiliki kontribusi nilai tambah bruto sebesar Rp. 3,821 triliun atau berkontribusi 0,226\% dari total nilai tambah bruto di Provinsi Jawa Timur. Kontribusi output dan nilai tambah bruto sub sektor komoditas kopi secara keseluruhan memiliki nilai rendah.
\end{abstract}




\section{PENDAHULUAN}

Sektor Perkebunan turut serta dalam upaya pengembangan wilayah yang berdampak terhadap masyarakat secara ekonomi maupun sosial (Tambunan, 2010).

Provinsi Jawa Timur adalah salah satu sentra penghasil kopi terbesar di Indonesia. Hal ini menunjukkan bahwa provinsi Jawa Timur merupakan daerah potensial untuk dikembangkannya komoditas kopi, dalam rangka meningkatkan perekonomian nasional melalui perannya dalam meningkatkan nilai Produk Domestik Regional Bruto (PDRB).

Potensi perkebunan yang dimiliki oleh provinsi Jawa Timur melalui PDRB tentunya diharapkan juga mampu menunjang perekonomian di wilayah Jawa Timur. Perhitungan Produk Domestik Regional Bruto (PDRB) sama dengan perhitungan Produk Domestik Bruto (PDB), (Badan Pusat Statistik, 2006). Untuk itu perlu diketahui mengenai kontribusi komoditas kopi melalui nilai Produk Domestik Regional Bruto (PDRB) komoditas kopi terhadap perekonomian provinsi Jawa Timur berdasarkan nilai input dan output yang digunakan (Daryanto dan Hafizrianda, 2010).

Analisis Input Output adalah suatu analisis yang menggambarkan atau mendeskripsikan perekonomian regional secara detail (Budiharsono, 2005). Kapasitas atau kemampuan produksi komoditas kopi di provinsi Jawa Timur juga dapat terlihat di Tabel Input-Output provinsi Jawa Timur.

Permasalahan di dalam penelitian ini adalah bagaimanakah kontribusi komoditas kopi terhadap perekonomian provinsi Jawa Timur. Adapun tujuan penelitian ini adalah untuk mengetahui: Kontribusi komoditas kopi melalui nilai Produk Domestik Regional Bruto (PDRB) yang terdiri dari nilai kontribusi output dan kontribusi nilai tambah bruto di provinsi Jawa Timur

Hipotesis dalam penelitian ini adalah kontribusi komoditas kopi terhadap perekonomian provinsi Jawa Timur adalah rendah.

\section{BAHAN DAN METODE}

Penentuan daerah digunakan purphosive method. Daerah penelitian berada di Provinsi Jawa Timur. Metode yang digunakan dalam penelitian lebih mengarah pada metode diskriptif dan analitis (Nazir, 1999). Untuk mengetahui kontribusi komoditas kopi bagi perekonomian provinsi Jawa Timur dapat dilihat dalam Tabel Input-Output Jawa Timur tahun 2015. Kemudian klasifikasi yang dianalisis adalah menggunakan klasifikasi tabel input output 44 x 44 . Kemudian untuk kriteria pengambilan keputusan dalam menjawab hipotesis adalah sebagai berikut.

Nilai Kontribusi Komoditas Kopi mempunyai nilai rendah apabila nilai kontribusi komoditas kopi lebih kecil atau sama dengan daripada $(\leq)$ nilai kontribusi kelompok sektor yang lain (tanaman pangan dan hortikultura, perkebunan lainnya, peternakan, kehutanan dan perikanan, pertambangan dan industri pengolahan).

Nilai Kontribusi Komoditas Kopi mempunyai nilai tinggi apabila nilai kontribusi komoditas kopi lebih besar atau sama dengan daripada $(\geq)$ nilai kontribusi kelompok sektor yang lain (tanaman pangan dan hortikultura, perkebunan lainnya, peternakan, kehutanan dan perikanan, pertambangan dan industri pengolahan).

\section{HASIL DAN PEMBAHASAN \\ Peranan dan Kontribusi Kopi Terhadap Perekonomian Provinsi Jawa Timur}

Indikator dari analisis ini adalah berupa analisis tentang struktur Permintaan Antara barang dan jasa di wilayah provinsi Jawa Timur, Struktur Output, dan nilai tambah yang menggambarkan peranan masing-masing sektor khususnya sektor 
komoditas kopi dalam perekonomian provinsi Jawa Timur.

\section{a. Kontribusi Terhadap Pembentukan Output}

1. Kontribusi Sektor Komoditas Kopi dan Sektor Komoditas Tanaman Pangan dan Hortikultura Terhadap Pembentukan Output

Sektor-sektor yang tergolong dari tanaman pangan dan hortikulturan terdiri dari sektor padi, jagung, kedelai, tanaman pangan lainnya, tanaman hortikultura semusim, tanaman hortikultura tahunan, dan tanaman hortikultura lainnya.

Tabel 1. Komposisi Output Sektor Kopi dan Tanaman Pangan dan Hortikultura di provinsi Jawa Timur

\begin{tabular}{cclrr}
\hline \multirow{2}{*}{$\begin{array}{c}\text { Pe- } \\
\text { ringkat }\end{array}$} & $\begin{array}{c}\text { Kode } \\
\text { sektor }\end{array}$ & Nama Sektor & Nilai Output & Peranan \\
\cline { 3 - 5 } & 11 & Kelapa & (Miliar Rupiah) & (Persen) \\
\hline 1 & 6 & Tebu & 15.507 & 0,487 \\
3 & 16 & Perkebunan Tahunan Lainnya & 11.222 & 0,353 \\
4 & 12 & Kopi & 5.895 & 0,185 \\
5 & 14 & Kakao & 4.247 & 0,133 \\
6 & 15 & Karet & 1.884 & 0,059 \\
7 & 7 & Tembakau & 1.876 & 0,058 \\
8 & 8 & Perkebunan Semusim Lainnya & 940 & 0,03 \\
9 & 13 & Teh & 56 & 0,002 \\
& & & 31 & 0,001 \\
\hline
\end{tabular}

Sumber: Tabel Input Output provinsi Jawa Timur, 2015 (diolah)

Keterangan: Persen diperoleh dari Nilai Output terhadap jumlah input keseluruhan Sektor (Kode 210)

tanaman hortikultura lainnya. Sektor komoditas kedelai mempunyai nilai komposisi output sebesar Rp. 2,4 triliun atau hanya mempunyai peranan sebesar $0,076 \%$ dari seluruh output yang tercipta di provinsi Jawa Timur. Kemudian sektor komoditas tanaman hortikultura lainnya mempunyai nilai komposisi output sebesar Rp. 713 miliar atau mempunyai peranan sebesar $0,022 \%$ dari seluruh output yang tercipta di provinsi Jawa Timur.

2. Kontribusi Sektor Komoditas Kopi dan Sektor Komoditas Tanaman Perkebunan Terhadap Pembentukan Output

Salah satu sektor yang menunjang perekonomian di provinsi Jawa Timur adalah sektor-sektor yang tergolong dalam
Nilai komposisi output sektor-sektor yang tergolong tanaman pangan dan hortikultura diatas apabila dilihat secara keseluruhan kemudian dibandingkan dengan nilai komposisi output sektor komoditas kopi dapat diketahui bahwa nilai komposisi output sektor komoditas kopi masih lebih tinggi daripada kedua sektor yang lain. Sektor-sektor yang mempunyai nilai komposisi output lebih rendah daripada nilai komposisi output sektor komoditas kopi terdiri dari sektor komoditas kedelai dan sektor komoditas 
output sektor komoditas kopi masih lebih tinggi daripada sektor-sektor yang lain selain dari ketiga komoditas utama diatas. Sektor-sektor yang mempunyai nilai komposisi output lebih rendah daripada nilai komposisi output sektor komoditas kopi terdiri dari sektor komoditas kakao, sektor komoditas karet, sektor komoditas tembakau, sektor perkebunan semusim lainnya dan sektor komoditas teh. Kemudian apabila dibandingkan data produksi tanaman perkebunan di provinsi Jawa Timur dapat diketahui bahwa jumlah produksi tertinggi belum tentu menunjukkan kemampuan suatu sub sektor dalam memberikan kontribusi terhadap perekonomian provinsi Jawa Timur. Khususnya untuk sub sektor komoditas kopi yang mempunyai nilai kontribusi output lebih besar daripada sub sektor komoditas tembakau. Jika dilihat dari kemampuan produksi sub sektor kopi masih lebih rendah daripada sub sektor tembakau akan tetapi justru jika dilihat dari nilai kontribusi output sub sektor komoditas kopi lebih besar daripada sub sektor tembakau. Hal ini dikarenakan kemampuan sub sektor kopi dalam

Tabel 2. Komposisi Output Sektor Kopi dan Tanaman Perkebunan Lainnya di provinsi Jawa Timur

\begin{tabular}{cclrr}
\hline \multirow{2}{*}{$\begin{array}{c}\text { Pe- } \\
\text { ringkat }\end{array}$} & $\begin{array}{c}\text { Kode } \\
\text { sektor }\end{array}$ & Nama Sektor & Nilai Output & Peranan \\
\cline { 3 - 5 } & 11 & Kelapa & (Miliar Rupiah) & (Persen) \\
\hline 1 & 6 & Tebu & 15.507 & 0,487 \\
3 & 16 & Perkebunan Tahunan Lainnya & 11.222 & 0,353 \\
4 & 12 & Kopi & 5.895 & 0,185 \\
5 & 14 & Kakao & 4.247 & 0,133 \\
6 & 15 & Karet & 1.884 & 0,059 \\
7 & 7 & Tembakau & 1.876 & 0,058 \\
8 & 8 & Perkebunan Semusim Lainnya & 940 & 0,03 \\
9 & 13 & Teh & 56 & 0,002 \\
& 13 & 31 & 0,001 \\
\hline
\end{tabular}

Sumber: Tabel Input Output provinsi Jawa Timur, 2015 (diolah)

Keterangan: Persen diperoleh dari Nilai Output terhadap jumlah input keseluruhan Sektor (Kode 210)

Tabel 3. Komposisi Output Sektor Kopi dan Peternakan di provinsi Jawa Timur

\begin{tabular}{cclrr}
\hline $\begin{array}{c}\text { Pe- } \\
\text { ringkat }\end{array}$ & $\begin{array}{c}\text { Kode } \\
\text { sektor }\end{array}$ & Nama Sektor & Nilai Output & Peranan \\
\hline 1 & 17 & Sapi & (Miliar Rupiah) & (Persen) \\
\hline 2 & 20 & Ayam & 27.831 & 0,874 \\
3 & 22 & Susu Segar & 11.076 & 0,348 \\
4 & 23 & Telur & 9.525 & 0,299 \\
5 & 19 & Domba dan Kambing & 8.563 & 0,269 \\
6 & 12 & Kopi & 7.998 & 0,251 \\
7 & 25 & Jasa Pertanian dan Perburuan & 4.247 & 0,133 \\
8 & 21 & Unggas Lainnya & 4.044 & 0,127 \\
9 & 24 & Ternak Lainnya & 206 & 0,006 \\
10 & 18 & Kerbau & 61 & 0,002 \\
\hline
\end{tabular}

Sumber: Tabel Input Output provinsi Jawa Timur, 2015 (diolah)

Keterangan: Persen diperoleh dari Nilai Output terhadap jumlah input keseluruhan Sektor (Kode 210)

memberikan kontribusi pembentukan output atau suatu produk bagi sub sektor yang lain justru lebih besar daripada sub sektor komoditas tembakau, artinya dengan perkataan lain bahwa daya serap oleh sub sektor yang lain terhadap produk sub sektor kopi lebih besar daripada produk sub sektor tembakau. 
3. Kontribusi Sektor Komoditas Kopi dan Sektor Komoditas Peternakan Terhadap Pembentukan output

Sektor komoditas peternakan merupakan salah satu sektor yang telah lama dikembangkan oleh provinsi Jawa Timur dan mampu menjelma menjadi salah satu sektor yang mampu menunjang perekonomian bagi provinsi Jawa Timur. Hal ini dapat digambarkan melalui nilai komposisi output yang dihasilkan oleh sektor-sektor yang tergolong di dalam sektor komoditas peternakan.

Sektor-sektor tersebut terdiri dari sektor komoditas sapi, kerbau, domba dan kambing, ayam, unggas lainnya, susu segar, telur, ternak lainnya, dan jasa pertanian dan perburuan. Dapat diketahui juga bahwa nilai komposisi output sektor komoditas kopi masih lebih tinggi daripada sektor yang lain terutama selain ketiga komoditas utama yang tergolong sektor komoditas peternakan. Sektor-sektor yang mempunyai nilai komposisi output lebih rendah daripada nilai komposisi output sektor komoditas kopi terdiri dari sektor komoditas jasa pertanian dan perburuan, sektor komoditas unggas lainnya, sektor komoditas ternak lainnya dan sektor komoditas kerbau. Sektor komoditas jasa pertanian dan perburuan mempunyai nilai kontribusi output sebesar Rp. 4 triliun atau mempunyai peranan sebesar $0,127 \%$ dari keseluruhan output yang tercipta di provinsi Jawa Timur. Kemudian Sektor komoditas unggas lainnya mempunyai nilai komposisi output sebesar Rp. 206 miliar atau hanya mempunyai peranan sebesar $0,006 \%$ dari seluruh output yang tercipta di provinsi Jawa Timur. Selanjutnya adalah sektor komoditas ternak lainnya yang mempunyai nilai komposisi output sebesar Rp. 61 miliar atau mempunyai peranan sebesar 0,002 \% dari keseluruhan output yang dihasilkan oleh provinsi Jawa Timur. Kemudian sektor komoditas kerbau mempunyai nilai komposisi output sebesar Rp. 56 miliar atau mempunyai peranan sebesar $0,002 \%$ dari seluruh output yang tercipta di provinsi Jawa Timur.

4. Kontribusi Sektor Komoditas Kopi dan Sektor Komoditas Kehutanan dan Perikanan Terhadap Pembentukan Output

Tabel 4. Komposisi Output Sektor Kopi dan Kehutanan dan peternakan di provinsi Jawa Timur

\begin{tabular}{cclrr}
\hline \multirow{2}{*}{$\begin{array}{c}\text { Pe- } \\
\text { ringkat }\end{array}$} & $\begin{array}{c}\text { Kode } \\
\text { sektor }\end{array}$ & \multicolumn{1}{c}{ Nama Sektor } & \multicolumn{1}{c}{ Nilai Output } & Peranan \\
\cline { 3 - 5 } & & (Miliar Rupiah) & (Persen) \\
\hline 1 & 30 & Ikan Darat dan Hasil Perikanan Darat & 31.238 & 0,982 \\
2 & 29 & Ikan Laut dan Hasil Perikanan Laut & 23.915 & 0,751 \\
3 & 27 & Kayu Rimba & 5.898 & 0,185 \\
4 & 26 & Kayu Jati & 4.603 & 0,145 \\
5 & 12 & Kopi & 4.247 & 0,133 \\
6 & 28 & Hasil Hutan Lainnya & 531 & 0,017 \\
\hline
\end{tabular}

Sumber: Tabel Input Output provinsi Jawa Timur, 2015 (diolah)

Keterangan: Persen diperoleh dari Nilai Output terhadap jumlah input keseluruhan Sektor (Kode 210)

Salah satu sektor yang menunjang perekonomian provinsi Jawa Timur adalah sektor-sektor yang tergolong di dalam sektor komoditas kehutanan dan perikanan. Hal ini dapat digambarkan melalui tabel input output provinsi Jawa Timur tahun
2015. Di dalam tabel input output provinsi Jawa Timur tahun 2015, sektor-sektor yang tergolong sektor komoditas kehutanan dan perikanan terdiri dari kayu jati, kayu rimba, hasil hutan lainnya, ikan laut dan hasil perikanan laut, dan ikan darat dan hasil 
perikanan darat. Dapat diketahui juga bahwa nilai komposisi output sektor komoditas kopi masih lebih tinggi daripada sektor komoditas hasil hutan lainnya. Sektor komoditas hasil hutan lainnya hanya mempunyai nilai kontribusi output sebesar Rp. 531 miliar atau mempunyai peranan $0,017 \%$ dari keseluruhan output yang tercipta di provinsi Jawa Timur. Sehingga dapat disimpulkan bahwa peranan atau kontribusi sektor komoditas kopi masih belum dominan daripada sektor-sektor yang tergolong sektor komoditas kehutanan dan perikanan dalam menunjang perekonomian provinsi Jawa Timur.

Hal ini menunjukkan bahwa pengembangan komoditas kopi di provinsi Jawa Timur masih belum optimal daripada sektor-sektor yang tergolong di dalam sektor komoditas kehutanan dan perikanan. Walaupun sektor komoditas kopi mempunyai nilai kontribusi output yang lebih besar daripada sektor komoditas hasil hutan lainnya.

Tabel 5. Komposisi Nilai Tambah Bruto Sektor Kopi dan Tanaman Pangan dan Hortikultura di provinsi Jawa Timur

\begin{tabular}{cclrr}
\hline \multirow{2}{*}{$\begin{array}{c}\text { Pe- } \\
\text { ringkat }\end{array}$} & $\begin{array}{c}\text { Kode } \\
\text { sektor }\end{array}$ & Nama Sektor & \multicolumn{1}{c}{ Nilai } & Peranan \\
\cline { 4 - 5 } & 1 & Padi & 50.558 & (Miliar Rupiah) \\
\hline 1 & 9 & Tanaman Hortikultura Tahunan & 14.945 & 0,894 \\
2 & 2 & Jagung & 14.518 & 0,859 \\
3 & 4 & Tanaman Pangan Lainnya & 8.711 & 0,515 \\
4 & 5 & Tanaman Hortikultura Semusim & 4.846 & 0,287 \\
5 & 12 & Kopi & 3.821 & 0,226 \\
6 & 3 & Kedelai & 1.797 & 0,106 \\
7 & 10 & Tanaman Hortikultura Lainnya & 675 & 0,04 \\
8 & & & & \\
\hline
\end{tabular}

Sumber: Tabel Input Output provinsi Jawa Timur, 2015 (diolah)

Keterangan: Persen diperoleh dari NTB sektor terhadap jumlah NTB keseluruhan Sektor (Kode 209)

\section{b. Kontribusi Terhadap Nilai Tambah Bruto}

1. Kontribusi Sektor Komoditas Kopi dan Sektor Komoditas Tanaman Pangan dan Hortikultura Terhadap Nilai Tambah Bruto

Sektor-sektor yang tergolong di dalam sektor komoditas tanaman pangan dan hortikultura mempunyai nilai yang lebih besar daripada nilai kontribusi output sektor komoditas kopi kecuali sektor komoditas kedelai dan sektor komoditas tanaman hortikultura lainnya. Sehingga dengan adanya hal tersebut dapat dimungkinkan juga terjadi pada kontribusi nilai tambah bruto sektor-sektor komoditas yang tergolong di dalam tanaman pangan dan hortikultura. Dapat disimpulkan bahwa nilai komposisi output sektor-sektor yang tergolong di dalam tanaman pangan dan hortikultura yang dihasilkan berbanding lurus dengan nilai tambah brutonya. Hal ini juga menunjukkan bahwa terdapat selain mempunyai kemampuan penciptaan output yang tinggi sektor-sektor yang tergolong di dalam tanaman pangan dan hortikultura juga mempunyai efektifitas di dalam penggunaan input dalam suatu kegiatan proses produksi suatu sektor yang menjadikan sektor-sektor yang tergolong di dalam tanaman pangan dan hortikultura sebagai bahan inputnya. 
Dapat diketahui juga apabila dibandingkan dengan ketiga komoditas utama sektor-sektor yang tergolong di dalam tanaman pangan dan hortikultura, sektor komoditas kopi masih lebih rendah. Nilai kontribusi nilai tambah bruto sektor komoditas kopi hanya mencapai Rp. 3,8 triliun atau mempunyai peranan sebesar $0,226 \%$ dari keseluruhan penciptaan nilai tambah bruto di provinsi Jawa Timur. Namun apabila dibandingkan secara keseluruhan dengan sektor-sektor yang tergolong di dalam tanaman pangan dan hortikultura dapat diketahui bahwa kontribusi nilai tambah bruto komoditas kopi masih lebih tinggi daripada sektor yang lain. Sektor-sektor yang tergolong di dalam tanaman pangan dan hortikultura tersebut terdiri dari sektor komoditas kedelai dan sektor komoditas tanaman hortikultura lainnya. Sektor komoditas kedelai mempunyai kontribusi nilai tambah bruto mencapai 1,7 triliun atau mempunyai peranan sebesar $0,106 \%$ dari keseluruhan penciptaan nilai tambah bruto di provinsi Jawa Timur. Selanjutnya adalah sektor komoditas tanaman hortikultura lainnya yang mempunyai nilai tambah bruto sebesar Rp. 675 miliar atau mempunyai peranan sebesar $0,04 \%$ dari keseluruhan penciptaan nilai tambah bruto di provinsi Jawa Timur. Sehingga dapat disimpulkan bahwa dari aspek efektifitas di dalam penggunaan input di dalam suatu kegiatan produksi, sektor komoditas kopi masih lebih efektif daripada sektor yang tergolong di dalam tanaman pangan dan hortikultura yang terdiri dari sektor komoditas kedelai dan sektor komoditas tanaman hortikultura lainnya.

2. Kontribusi Sektor Komoditas Kopi dan Sektor Komoditas Tanaman Perkebunan Terhadap Nilai Tambah Bruto

Tabel 8. Komposisi Nilai Tambah Bruto Sektor Kopi dan Tanaman Perkebunan Lainnya di provinsi Jawa Timur

\begin{tabular}{cclrr}
\hline \multirow{2}{*}{$\begin{array}{c}\text { Pe- } \\
\text { ringkat }\end{array}$} & $\begin{array}{c}\text { Kode } \\
\text { sektor }\end{array}$ & Nama Sektor & Nilai Output & Peranan \\
\cline { 3 - 5 } & 11 & Kelapa & (Miliar Rupiah) & (Persen) \\
\hline 1 & 6 & Tebu & 14.207 & 0,841 \\
3 & 16 & Perkebunan Tahunan Lainnya & 8.298 & 0,491 \\
4 & 12 & Kopi & 5.386 & 0,319 \\
5 & 14 & Kakao & 3.821 & 0,226 \\
6 & 15 & Karet & 1.719 & 0,102 \\
7 & 7 & Tembakau & 1.703 & 0,101 \\
8 & 13 & The & 667 & 0,039 \\
9 & 8 & Perkebunan Semusim Lainnya & 271 & 0,016 \\
& & & 44 & 0,003 \\
\hline
\end{tabular}

Sumber: Tabel Input Output provinsi Jawa Timur, 2015 (diolah)

Keterangan: Persen diperoleh dari NTB sektor terhadap jumlah NTB keseluruhan Sektor (Kode 209)

Nilai kontribusi output sektor komoditas kopi apabila dibandingkan secara keseluruhan dengan sektor-sektor yang tergolong di dalam sektor komoditas tanaman perkebunan masih lebih besar daripada sektor-sektor yang lain kecuali sektor komoditas kelapa, sektor komoditas tebu dan sektor komoditas tanaman perkebunan tahunan lainnya. Sehingga dengan adanya hal tersebut dapat dimungkinkan juga terjadi pada kontribusi nilai tambah bruto sektor-sektor komoditas 
yang tergolong di dalam tanaman perkebunan.

Dapat diketahui juga apabila dibandingkan secara keseluruhan dengan sektor-sektor yang tergolong di dalam tanaman perkebunan bahwa kontribusi nilai tambah bruto komoditas kopi masih lebih tinggi daripada sektor yang lain. Sektor-sektor yang tergolong di dalam tanaman perkebunan lainnya tersebut terdiri dari sektor komoditas kakao, sektor komoditas karet, sektor komoditas tembakau, sektor komoditas teh, dan sektor komoditas perkebunan semusim lainnya. Sektor komoditas kakao mempunyai kontribusi nilai tambah bruto mencapai 1,719 triliun atau mempunyai peranan sebesar $0,102 \%$ dari keseluruhan penciptaan nilai tambah bruto di provinsi Jawa Timur.

Selanjutnya adalah sektor komoditas karet yang mempunyai nilai tambah bruto sebesar Rp. 1,703 triliun atau mempunyai peranan sebesar $0,101 \%$ dari keseluruhan penciptaan nilai tambah bruto di provinsi Jawa Timur. Kemudian sektor komoditas tembakau yang mempunyai kontribusi nilai tambah bruto sebesar Rp. 667 miliar atau mempunyai peranan sebesar 0,039\% dari keseluruhan penciptaan nilai tambah bruto di provinsi Jawa Timur.

Selanjutnya adalah sektor komoditas teh yang mempunyai kontribusi nilai tambah bruto sebesar Rp. 271 miliar atau mempunyai peranan sebesar $\quad 0,016 \%$ dari keseluruhan penciptaan nilai tambah bruto di provinsi Jawa Timur. Kemudian sektor komoditas perkebunan semusim lainnya yang mempunyai kontribusi nilai tambah bruto sebesar Rp. 44 miliar atau mempunyai peranan sebesar $0,003 \%$ dari keseluruhan penciptaan nilai tambah bruto di provinsi Jawa Timur. Sehinnga dapat disimpulkan bahwa dari aspek efektifitas di dalam penggunaan input di dalam suatu kegiatan produksi, sektor komoditas kopi masih lebih efektif daripada sektor yang tergolong di dalam tanaman perkebunan yang terdiri dari sektor komoditas kakao, sektor komoditas karet, sektor komoditas tembakau, sektor komoditas teh, dan sektor komoditas perkebunan semusim lainnya. Apabila dibandingkan data produksi tanaman perkebunan di provinsi Jawa Timur dapat diketahui bahwa jumlah produksi tertinggi belum tentu menunjukkan kemampuan suatu sub sektor dalam memberikan kontribusi terhadap perekonomian provinsi Jawa Timur. Khususnya untuk sub sektor komoditas kopi yang mempunyai nilai kontribusi nilai tambah bruto lebih besar daripada sub sektor komoditas tembakau. Jika dilihat dari kemampuan produksi sub sektor kopi masih lebih rendah daripada sub sektor tembakau akan tetapi justru jika dilihat dari nilai kontribusi nilai tambah bruto sub sektor komoditas kopi lebih besar daripada sub sektor tembakau. Hal ini menunjukkan bahwa sub sektor komoditas kopi mempunyai nilai tambah yang lebih besar daripada sub sektor tembakau, artinya dengan perkataan lain bahwa sub sektor komoditas kopi ketika dalam bentuk produk atau output kemudian digunakan sebagai input produksi bagi sub sektor yang lain memliki nilai yang lebih efisien jika dibandingkan dengan sub sektor tembakau.

3. Kontribusi Sektor Komoditas Kopi dan Peternakan Terhadap Nilai Tambah Bruto 
Sektor-sektor yang tergolong di dalam sektor komoditas kehutanan dan perikanan, apabila dibandingkan dari aspek nilai kontribusi outputnya terhadap sektor komoditas kopi mempunyai nilai yang lebih besar kecuali sektor komoditas hasil hutan lainnya.

Dapat diketahui juga apabila dibandingkan secara keseluruhan dengan sektor-sektor yang tergolong di dalam sektor komoditas peternakan bahwa kontribusi nilai tambah bruto komoditas kopi masih lebih tinggi daripada sektor yang lain. Sektor-sektor yang tergolong di Tabel 9.Komposisi Nilai Tambah Bruto Sektor Kopi dan Peternakan di provinsi Jawa Timur

\begin{tabular}{|c|c|c|c|c|}
\hline \multirow{2}{*}{$\begin{array}{l}\text { Pe- } \\
\text { ringkat }\end{array}$} & \multirow{2}{*}{$\begin{array}{l}\text { Kode } \\
\text { sektor }\end{array}$} & \multirow{2}{*}{ Nama Sektor } & \multirow{2}{*}{$\frac{\text { Nilai Output }}{\text { (Miliar Rupiah) }}$} & \multirow{2}{*}{$\begin{array}{l}\text { Peranan } \\
\text { (Persen) }\end{array}$} \\
\hline & & & & \\
\hline 1 & 17 & Sapi & 20.281 & 1,2 \\
\hline 2 & 20 & Ayam & 7.257 & 0,429 \\
\hline 3 & 22 & Susu Segar & 6.452 & 0,382 \\
\hline 4 & 19 & Domba dan Kambing & 6.334 & 0,375 \\
\hline 5 & 23 & Telur & 5.682 & 0,336 \\
\hline 6 & 12 & Kopi & 3.821 & 0,226 \\
\hline 7 & 25 & Jasa Pertanian dan Perburuan & 2.740 & 0,162 \\
\hline 8 & 21 & Unggas Lainnya & 143 & 0,008 \\
\hline 9 & 24 & Ternak Lainnya & 48 & 0,003 \\
\hline 10 & 18 & Kerbau & 44 & 0,003 \\
\hline
\end{tabular}

Sumber: Tabel Input Output provinsi Jawa Timur, 2015 (diolah)

Keterangan: Persen diperoleh dari NTB sektor terhadap jumlah NTB keseluruhan Sektor (Kode 209)

Tabel 10. Komposisi Nilai Tambah Bruto Sektor Kopi dan Kehutanan dan Perikanan di provinsi Jawa Timur

\begin{tabular}{cclrr}
\hline \multirow{2}{*}{$\begin{array}{c}\text { Pe- } \\
\text { ringkat }\end{array}$} & $\begin{array}{c}\text { Kode } \\
\text { sektor }\end{array}$ & \multicolumn{1}{c}{ Nama Sektor } & Nilai Output & Peranan \\
\cline { 3 - 5 } & 30 & Ikan Darat dan Hasil Perikanan Darat & (Miliar Rupiah) & (Persen) \\
\hline 1 & 29 & Ikan Laut dan Hasil Perikanan Laut & 22.530 & 1,333 \\
2 & 27 & Kayu Rimba & 19.370 & 1,146 \\
3 & 26 & Kayu Jati & 4.910 & 0,291 \\
4 & 12 & Kopi & 3.928 & 0,232 \\
5 & 28 & Hasil Hutan Lainnya & 3.821 & 0,226 \\
6 & & 464 & 0,027 \\
\hline
\end{tabular}

Sumber: Tabel Input Output provinsi Jawa Timur, 2015 (diolah)

Keterangan: Persen diperoleh dari NTB sektor terhadap jumlah NTB keseluruhan Sektor (Kode 209)

143 miliar atau mempunyai peranan sebesar $0,008 \%$ dari keseluruhan penciptaan nilai tambah bruto di provinsi Jawa Timur.
Kemudian sektor komoditas ternak lainnya yang mempunyai kontribusi nilai tambah bruto sebesar Rp. 48 miliar atau mempunyai peranan sebesar $0,003 \%$ dari 
keseluruhan penciptaan nilai tambah bruto di provinsi Jawa Timur. Selanjutnya adalah sektor komoditas kerbau yang mempunyai kontribusi nilai tambah bruto sebesar Rp. 44 miliar atau mempunyai peranan sebesar $0,003 \%$ dari keseluruhan penciptaan nilai tambah bruto di provinsi Jawa Timur. Sehingga dapat disimpulkan bahwa dari aspek efektifitas di dalam penggunaan input di dalam suatu kegiatan produksi, sektor komoditas kopi masih lebih efektif daripada sektor yang tergolong di dalam sektor komoditas peternakan yang terdiri dari sektor komoditas jasa pertanian dan perburuan, sektor komoditas unggas lainnya, sektor komoditas ternak lainnya dan sektor komoditas kerbau.

\section{Kontribusi Sektor Komoditas Kopi dan} Sektor Komoditas Kehutanan dan Perikanan Terhadap Nilai Tambah Bruto

Sektor-sektor yang tergolong di dalam sektor komoditas kehutanan dan perikanan, apabila dibandingkan dari aspek nilai kontribusi outputnya terhadap sektor komoditas kopi mempunyai nilai yang lebih besar kecuali sektor komoditas hasil hutan lainnya. Sehingga dengan adanya hal tersebut dapat dimungkinkan juga terjadi pada kontribusi nilai tambah bruto sektorsektor komoditas yang tergolong di dalam sektor komoditas kehutanan dan perikanan.

Dapat diketahui juga apabila dibandingkan dengan ketiga komoditas utama sektor-sektor yang tergolong di dalam sektor komoditas kehutanan dan perikanan, sektor komoditas kopi masih lebih rendah. Nilai kontribusi nilai tambah bruto sektor komoditas kopi hanya mencapai Rp. 3,8 triliun atau mempunyai peranan sebesar $0,226 \%$ dari keseluruhan penciptaan nilai tambah bruto di provinsi Jawa Timur. Namun apabila dibandingkan secara keseluruhan dengan sektor-sektor yang tergolong di dalam tanaman pangan dan hortikultura dapat diketahui bahwa kontribusi nilai tambah bruto komoditas kopi masih lebih tinggi daripada sektor yang lain. Sektor-sektor yang tergolong di dalam sektor komoditas kehutanan dan perikanan tersebut adalah sektor komoditas hasil hutan lainnya. Sektor komoditas hasil hutan lainnya hanya mempunyai kontribusi nilai tambah bruto mencapai Rp. 464 miliar atau mempunyai peranan sebesar $0,027 \%$ dari keseluruhan penciptaan nilai tambah bruto di provinsi Jawa Timur. Sehingga dapat disimpulkan bahwa dari aspek efektifitas di dalam penggunaan input di dalam suatu kegiatan produksi, sektor komoditas kopi masih lebih efektif daripada sektor komoditas hasil hutan lainnya.

\section{KESIMPULAN}

Dalam perekonomian provinsi Jawa Timur tahun 2015 menunjukkan bahwa komoditas kopi mempunyai peranan dan kontribusi melalui nilai kontribusi output sebesar Rp. 4,247 triliun atau berperan $0,133 \%$ dari keseluruhan penciptaan output di provinsi Jawa Timur serta mempunyai kontribusi nilai tambah bruto sebesar Rp. 3,821 triliun atau berperan $0,226 \%$ dari keseluruhan penciptaan nilai tambah bruto di provinsi Jawa Timur. Kontribusi Output dan Nilai Tambah Bruto sub sektor komoditas kopi secara keseluruhan mempunyai nilai yang rendah, tetapi berdasarkan komposisi kontribusi output dan nilai tambah bruto sub sektor komoditas kopi dan sektor-sektor yang tergolong di dalam tanaman perkebunan lainnya, sub sektor komoditas kopi mempunyai peranan lebih besar daripada sub sektor komoditas kakao, karet, 
tembakau, perkebunan semusim lainnya dan teh. Saran yang dapat disampaikan adalah meningkatkan dan mengoptimalisasi kebijakan pemerintah daerah di sektor hulu dan hilir terhadap pengembangan komoditas kopi di provinsi Jawa Timur. Dari aspek hulu dapat dilakukan dengan progam intensifikasi, bantuan benih, pupuk dan peremajaan tanaman kopi dalam menunjang kegiatan produksi komoditas kopi. Kemudian dari aspek hilir diutamakan kebijakan yang mampu mendorong sektor industri pengolahan untuk meningkatkan penggunaan output sektor komoditas kopi.

\section{DAFTAR PUSTAKA}

BPS. 2016. Provinsi Jawa Timur Dalam Angka 2016. Surabaya: Badan Pusat Statistik Jawa Timur.

BPS. 2015. Tabel Input Output Jawa Timur. Surabaya: Badan Pusat Statistik Jawa Timur.

BPS. 2006. Tabel Input Output Jawa Timur. Surabaya: Badan Pusat Statistik Jawa Timur.

Budiharsono, S. 2005. Teknik Analisa Pembangunan Wilayah Pesisir dan Lautan. Jakarta: PT. Pradnya Paramita.

Daryanto, Arif dan Hafizrianda, Yundy. 2010. Analisis Input-Output \& Social Accounting Matrix. Bogor: PT. Penerbit IPB Press.

Nazir, M. 1999. Metode Penelitian. Jakarta: Ghalia.

Tambunan, Tulus. 2010. Pembangunan Pertanian dan Ketahanan Pangan. Jakarta: Penerbit Universitas Indonesia (UI-Press). 